\title{
THE EFFECTIVENESS OF SULFLURAMID IN SARDINE BAIT FOR CONTROL OF WASPS (HYMENOPTERA: VESPIDAE)
}

\author{
E.B. SPURR
}

\author{
Manaaki Whenua - Landcare Research, P.O. Box 31-011, Christchurch
}

\section{SUMMARY}

Sardine bait containing $1 \%, 0.5 \%$, or $0.25 \%$ sulfluramid reduced wasp numbers at nests within $50 \mathrm{~m}$ of bait stations by $90 \%$ after $10-12$ days. The nests in which wasps survived for longer than 10-12 days all had pre-poison traffic counts of more than $50 \mathrm{wasps} / \mathrm{min}$. Wasp survival in nests within $150 \mathrm{~m}$ of bait stations was significantly lower than in nests further away. Sulfluramid took 10-12 days to achieve the same reduction in wasp numbers achieved by sodium monofluoroacetate (1080) in 1-2 days. However, it should be safer to non-target species. Keywords: Hymenoptera, Vespidae, insect control, baits, sulfluramid

\section{INTRODUCTION}

Two species of introduced social wasps (Hymenoptera: Vespidae), the common wasp (Vespula vulgaris (L.)) and German wasp (V. germanica $(\mathrm{F})$.$) , are a serious$ problem in New Zealand (Spurr 1991a,b). Control of wasps is currently hampered because there is no effective poison bait registered with the Pesticides Board for public use. Sodium monofluoroacetate (1080) in sardine bait is highly effective at reducing wasp numbers in forest picnic areas (Spurr 1991a), but is registered for use only by government employees.

Sulfluramid $\left(\mathrm{C}_{10} \mathrm{H}_{6} \mathrm{~F}_{1} \mathrm{NO}_{2} \mathrm{~S}\right)$, an organofluorine insecticide, is a candidate for registration for public use. It is a slow-acting, odourless, white, organic compound that is stable in sunlight, insoluble in water, immobile in soil, and has an acute oral $\mathrm{LD}_{50}$ in laboratory rats of $2350 \mathrm{mg} / \mathrm{kg}$ (cf. $0.2 \mathrm{mg} / \mathrm{kg}$ for 1080) (Griffin Corporation, unpubl. data). It is registered for public use in the USA under the trade name Finitron to control household ants and cockroaches (Worthing and Hance 1991), and in Brazil against leaf-cutting ants (J. Mares, pers. comm.).

This paper reports research in support of the registration of sulfluramid in sardine bait for control of social wasps in forest picnic areas.

\section{METHODS}

Sulfluramid (technical powder, $>98 \%$ purity, manufactured by Griffin Corporation, USA) was added to canned sardine cat-food (Wonder Cat, packed by Pataya Food Industries Ltd, Samutsakorn, Thailand), mixed for about $30 \mathrm{~s}$ in a cake mixer, and stored at $-18^{\circ} \mathrm{C}$. The bait was removed from the freezer the day before use.

Poison-baiting trials were done adjacent to beech (Nothofagus solandri var. cliffortioides) forest at Mt Thomas, Canterbury. The beech trees were heavily infested with the scale insect, Ultracoelostoma assimile. Honeydew produced by the scale insect is an important food resource for wasps. Wasps, predominantly common wasps, were abundant in the area (Spurr 1991a,b). Preliminary trials in autumn 1991 showed that wasps collected similar amounts of bait containing no sulfluramid and bait containing $1 \%$ sulfluramid (E.B. Spurr unpubl. data).

\section{Trial design}

Bait containing 1\% sulfluramid was tested in autumn 1991. Methods followed Spurr $(1991 \mathrm{a}, \mathrm{b})$. The wasp nests monitored in the poisoned area $(\mathrm{n}=12)$ were all within $10 \mathrm{~m}$ of a bait station $(\mathrm{n}=25)$. Sixteen nests were monitored in a non-poisoned area $1 \mathrm{~km}$ away. Non-toxic bait was put in bait stations in both areas on 3-5 April. On 5 April, non-toxic bait was left out for 1 hour before being replaced with toxic bait in

Proc. 46th N.Z. Plant Protection Conf. 1993: 307-312 
the poisoned area. Wasps collected about $4.8 \mathrm{~kg}$ of toxic bait the first day and $1.2 \mathrm{~kg}$ the second day before the bait ran out. Non-toxic bait was put in bait stations again 7 days after poison-baiting to determine whether surviving wasps would still come to baits.

Bait containing $0.5 \%$ sulfluramid was tested in autumn 1992. Seven of the wasp nests monitored were within $10 \mathrm{~m}$ of a bait station $(n=40), 36$ were $10-150 \mathrm{~m}$ away, and 16 were $150-250 \mathrm{~m}$ away. Only the seven nests within $10 \mathrm{~m}$ of bait stations were used for comparison with the 1991 trial. The other nests were used to determine the effect of distance from bait stations on success of poison-baiting. Six nests were monitored in a non-poisoned area $2 \mathrm{~km}$ away. Non-toxic bait was put in bait stations on 25-31 March, and toxic bait on 1-3 April. Wasps collected about $3.9 \mathrm{~kg}$ of toxic bait the first day, $0.9 \mathrm{~kg}$ the second day, and $0.3 \mathrm{~kg}$ the third day. Non-toxic bait was not put out after poison-baiting.

Baits containing $1 \%$ and $0.5 \%$ sulfluramid were re-tested in autumn 1993, and compared with bait containing $0.25 \%$ sulfluramid. The $1 \%$ and $0.5 \%$ poison areas were $0.5 \mathrm{~km}$ apart, and the $0.25 \%$ poison area was $7 \mathrm{~km}$ away. All nests monitored in the poisoned areas were within $50 \mathrm{~m}$ of a bait station (Table 1). Thirty-five nests were monitored in a non-poisoned area at least $1 \mathrm{~km}$ away from the poisoned areas. Nontoxic bait was put in bait stations on 23-26 March. On 26 March, non-toxic bait was left out for 1 hour before being replaced with toxic bait in the poisoned area. Wasps collected about $8 \mathrm{~kg}$ of toxic bait in each area the first day and $7.2 \mathrm{~kg}$ in each area over the next 2 days. The bait ran out in the $0.25 \%$ poison area on the second day. Non-toxic bait was put out in all areas 7 and 14 days after poison-baiting.

Impact of poison-baiting on wasp numbers

The instantaneous number of wasps and non-target species collecting bait and the number of wasps/minute leaving or entering nests in paired poisoned and nonpoisoned areas was counted for at least 3 days before and up to 39 days after poisonbaiting (see Table 1 for sample sizes). Wasp numbers were declining naturally when the trials were done. Consequently, a corrected percent reduction in poisoned areas was obtained from the formula, $(1-\%$ reduction in non-poisoned areas $/ \%$ reduction in poisoned areas) $\times 100$. Least significant differences were calculated from the formula given by Andrews et al. (1980). The impact of poisoning was determined from a repeated measures analysis of variance of the raw data after $\ln (x+1)$ transformation. The number of wasps and honey bees collecting honeydew from beech trees was also estimated before and after poison-baiting.

TABLE 1: The effect on the number of wasps collecting bait from bait stations $10 \mathrm{~m}$ apart and on the number of wasps/minute leaving or entering nests 0-50 $\mathrm{m}$ from bait stations 7 days after poison-baiting with $1 \%$, $0.5 \%$, or $0.25 \%$ sulfluramid in sardine cat-food in Mt Thomas Forest, Canterbury.

\begin{tabular}{|c|c|c|c|c|c|c|}
\hline \multirow{3}{*}{$\begin{array}{l}\text { Sulfluramid } \\
\text { concentration } \\
\text { in baits }\end{array}$} & \multicolumn{3}{|c|}{ Wasps/bait station } & \multicolumn{3}{|c|}{ Wasps/min/nest } \\
\hline & pre-p & ison & $\%$ & pre-p & ison & $\%$ \\
\hline & mean & (n) & reduction & mean & (n) & reduction \\
\hline \multicolumn{7}{|l|}{ 1991-92 trials } \\
\hline $1.0 \%$ sulfluramid & 14.0 & (25) & 99 & 27.8 & (12) & 84 \\
\hline $0.5 \%$ sulfluramid & 13.5 & (40) & -1 & 41.9 & (7) & 70 \\
\hline \multicolumn{7}{|l|}{1993 trials } \\
\hline $1.0 \%$ sulfluramid & 19.5 & (67) & 99 & 54.9 & (22) & 81 \\
\hline $0.5 \%$ sulfluramid & 12.0 & (65) & 98 & 36.6 & (17) & 75 \\
\hline $0.25 \%$ sulfluramid & 14.4 & (40) & 70 & 44.1 & (19) & 76 \\
\hline
\end{tabular}

$\mathrm{n}=$ number of bait stations or nests. $1=$ not determined. 
RESULTS

The number of wasps collecting bait containing $1 \%, 0.5 \%$, and $0.25 \%$ sulfluramid decreased by $35 \%, 7 \%$, and $0 \%$, respectively, after the first day of poison-baiting, $86 \%$, $78 \%$, and $42 \%$ after 3 days, and $99 \%, 98 \%$, and $70 \%$ after 7 days (Table 1 ). This is mostly greater than the reduction in the number of wasps leaving or entering nests (e.g., see Table 1 for the results after 7 days), probably because wasps collecting bait are the ones most likely to be directly affected by poisoning.

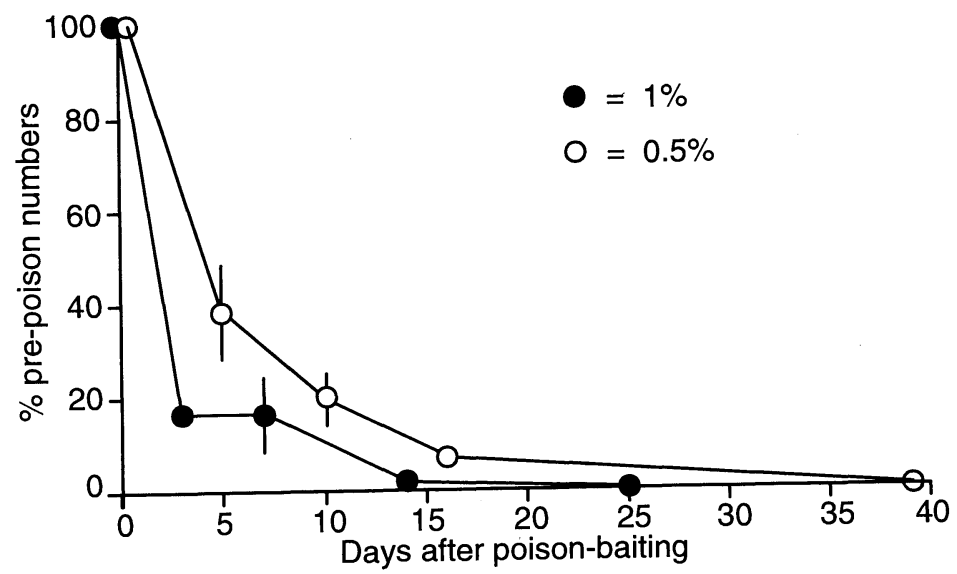

Figure 1: Wasp numbers/minute, as a percentage of pre-poison numbers, leaving or entering nests within $10 \mathrm{~m}$ of baits containing $1 \%$ and $0.5 \%$ sulfluramid, Mt Thomas Forest, April 1991 and 1992, respectively. Vertical lines represent least significant differences (too small to show for some points).

Compared to the number of wasps leaving or entering nests in non-poisoned areas, wasp traffic at nests within $10 \mathrm{~m}$ of bait stations in the 1991 and 1992 trials was reduced by about $90 \%$ after 10 days with $1 \%$ sulfluramid but only after 14 days with $0.5 \%$ sulfluramid (Fig. 1). There were no significant differences in the reductions achieved with $1 \%, 0.5 \%$, or $0.25 \%$ sulfluramid after 7 days in the 1993 trial $(\mathrm{F}=1.773, \mathrm{df}=2,55$, $\mathrm{P}=0.179 \cdot \mathrm{Fig}$. 2). Wasp traffic at nests within $50 \mathrm{~m}$ of bait stations was reduced by about $\mathrm{P}=0.179$; Fig. 2). Wasp and $99 \%$ after 14 days with all three concentrations (Fig. 2). After 14 days, about $86 \%$ of nests in the poisoned areas $(n=58)$, but no nests in the nonpoisoned $(n=34)$ area had died out. The nests in the poisoned areas in which wasps poisoned $(\mathrm{n}=34)$ area had died out. The nall had pre-poison counts of $>50 \mathrm{wasps} / \mathrm{min}$ (average $64.8 \mathrm{wasps} / \mathrm{min}$ reduced to $0.8 \mathrm{wasps} / \mathrm{min}$ after 14 days).

The effectiveness of poison-baiting was influenced by distance of wasp nests from bait stations (Fig. 3). There was no statistical difference in wasp mortality in nests 0 $50 \mathrm{~m}, 50-100 \mathrm{~m}$, or $100-150 \mathrm{~m}$ from bait stations 5 days after poison-baiting with $0.5 \%$ sulfluramid in $1992(\mathrm{~F}=0.235, \mathrm{df}=2,40, \mathrm{P}=0.792)$. However, wasp mortality in these sulfluramid in $1992(\mathrm{~F}=0.235, \mathrm{df}=2,40, \mathrm{P}=0.792)$. How never, whe than $150 \mathrm{~m}$ from bait stations $(\mathrm{n}=16)(\mathrm{F}=18.246, \mathrm{df}=1,57, \mathrm{P}<0.001)$. The slight decline in wasp numbers in stations $(\mathrm{n}=16)(\mathrm{F}=1 \mathrm{~m}$ from bait stations compared to nests in the non-poisoned area indicates that poison-baiting also had an impact on wasps in some of these nests. The indective distance of baits containing $1 \%$ or $0.25 \%$ sulfluramid could not be determined because insufficient nests were found $50-150 \mathrm{~m}$ from bait stations in trials with these concentrations. 


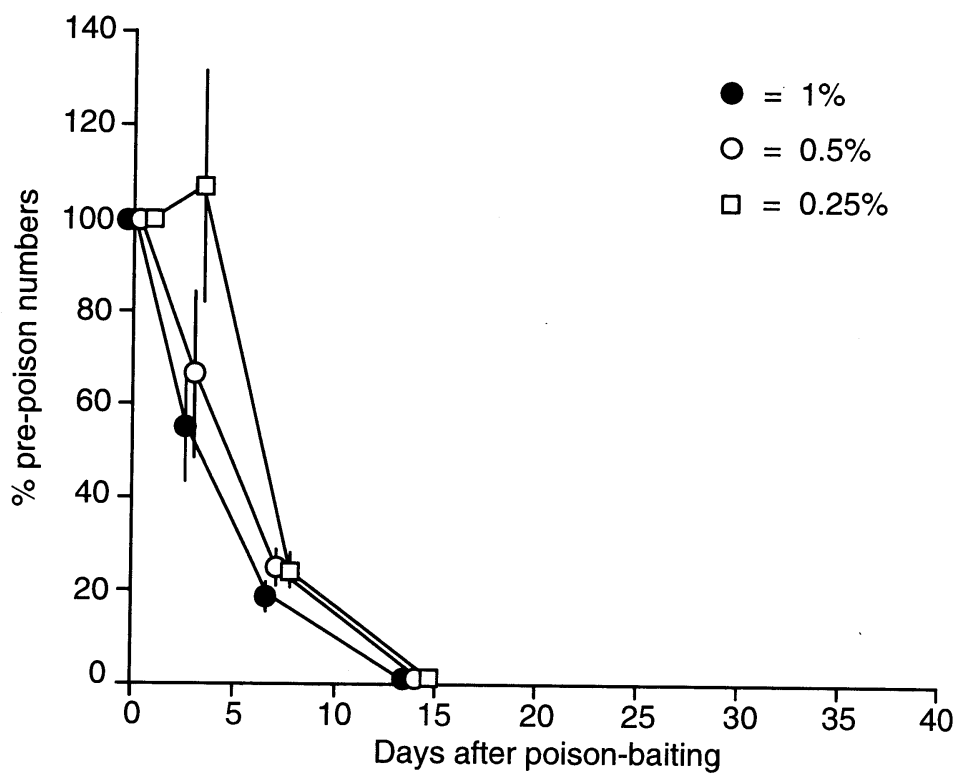

Figure 2: Wasp numbers/minute, as a percentage of pre-poison numbers, leaving or entering nests within $50 \mathrm{~m}$ of baits containing $1 \%, 0.5 \%$, and $0.25 \%$ sulfluramid, Mt Thomas Forest, March 1993. Vertical lines represent least significant differences (too small to show for some points).

The number of wasps collecting honeydew from beech trees within $50 \mathrm{~m}$ of the bait stations decreased by more than $99 \%$ in all poisoned areas 7 days after poison-baiting, whereas the number of honey bees collecting honeydew increased at least 10-fold.

Non-target species present on pre-feed baits were occasional unidentified flies (average $0.006 / \mathrm{bait}$ for all trials), honey bees $(0.001 / \mathrm{bait})$, and unidentified solitary wasps (0.001/bait) (cf. more than 12 social wasps/bait; Table 1). Seven days after poison-baiting, the number of flies had increased to 0.2 /bait, honey bees to $0.003 / \mathrm{bait}$, and solitary wasps to $0.02 /$ bait.

\section{DISCUSSION}

Sardine cat-food containing $1 \%, 0.5 \%$, or $0.25 \%$ sulfluramid was very effective at reducing wasp numbers in nests in Mt Thomas Forest. The effective distance of 150 $\mathrm{m}$ with $0.5 \%$ sulfluramid was similar to that with $1 \% 1080$ (Spurr 1991a) and similar to the distance within which most wasps forage from their nests (E.B. Spurr unpubl. data). However, sulfluramid acted more slowly than 1080 . Wasps continued collecting bait containing $1 \%$ sulfluramid for 2-3 days compared to only 2-3 hours for bait containing $1 \% 1080$. Wasp traffic at nests was reduced by $90 \%$ after about 10 days with $1 \%$ sulfluramid compared to $1-2$ days with $1 \% 1080$ (Spurr 1991a). The slow-acting nature of sulfluramid is offset by the advantage of a high $\mathrm{LD}_{50}$ in several mammals and birds (Worthing and Hance 1991), indicating a low risk to non-target vertebrates (e.g., humans, dogs, cats). Sulfluramid is at least as effective as alternative toxins that have been tested such as avermectin B1 (Dymock et al. 1991) and hydramethylnon (Spurr 1991b).

Bait containing $1 \%$ sulfluramid did not reduce wasp numbers in nests within 50 $\mathrm{m}$ of bait stations significantly more, or more rapidly, than did bait with $0.5 \%$ or $0.25 \%$ sulfluramid in these limited trials. However, bait containing $1 \%$ sulfluramid should be 


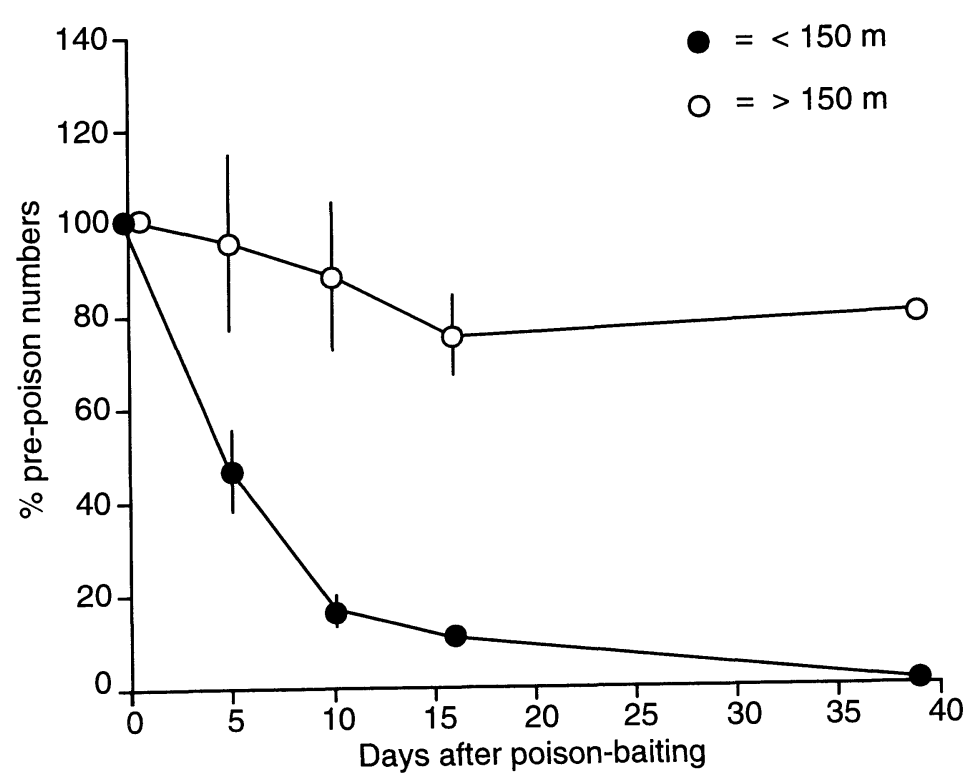

Figure 3: Wasp numbers/minute, as a percentage of pre-poison numbers, leaving or entering nests less than or more than $150 \mathrm{~m}$ from baits containing 0.5\% sulfluramid, Mt Thomas Forest, April 1992. Vertical lines represent least significant differences (too small to show for some points).

more effective than less toxic bait at distant nests because occasional foragers from these nests collect only a small amount of bait.

Wasps were given bait for 2-3 days in these trials, but perhaps the same results could be obtained with only 1 day's baiting, saving time and costs. Bait containing $1 \%$ sulfluramid put out for 1 day may be more cost-effective than less toxic bait put out for 2-3 days. It would also have less exposure to non-target species.

Few non-target species were attracted to the sardine baits in these trials, so there was little risk of direct poisoning. However, there was an unknown risk of secondary poisoning to scavengers such as ants that might eat poisoned wasps and larvae.

The effect of sulfluramid on wasp populations was tested only at the end of the wasp season (March-April) when numbers were declining naturally. Correcting for natural wasp mortality (see methods) may have resulted in underestimates of the potential wasp mortality from poison-baiting earlier in the season when wasp numbers are increasing or stable. Trials are needed in January-February. The effectiveness of sulfluramid in sardine cat-food was also tested only in a forested environment where honeydew was abundant. Trials are needed in other areas (e.g.,urban areas), where the attractiveness of sardine baits to wasps may be different.

Although further research is required, these results indicate that sulfluramid should now be registered for limited sale at concentrations of $1 \%, 0.5 \%$, or $0.25 \%$ in sardine cat-food because of high public demand (e.g., from beekeepers) for a poisonbait for wasp control.

\section{ACKNOWLEDGEMENTS}

This research was funded partly by Elliott Chemicals Ltd, Auckland, Griffin Corporation, USA, and the Foundation for Research, Science and Technology. I thank Carter Holt Harvey Ltd, Rangiora, for permission to work in Mt Thomas Forest, K.W. 
Drew for field assistance, C.M. Frampton for statistical advice, J. Mares and M. Rudge for comments on the manuscript, and J. Orwin for editorial comments.

\section{REFERENCES}

Andrews, H.P., Snee, R.D. and Sarner, M.H., 1980. Graphical display of means. Amer. Stat. 34: 195-199.

Dymock, J.J., Forgie, S.A. and Wigley, P.J., 1991. The responses of German wasps, Vespula germanica, to ingestion of the microbial toxin, avermectin B1.Proc. 44th N.Z. Weed and Pest Control Conf: : 38-41.

Spurr, E.B., 1991a. Reduction of wasp (Hymenoptera: Vespidae) populations by poison-baiting; experimental use of sodium monofluoroacetate (1080) in canned sardine. N.Z. J. Zool. 18: 215-222.

Spurr, E.B., 1991b. Wasp control by poison baiting: Experimental use of hydramethylnon in canned sardine bait. Proc. 44th N.Z. Weed and Pest Control Conf: $42-46$.

Worthing, C.R. and Hance, R.J., 1991. The Pesticide Manual: A World Compendium. British Crop Protection Council, Farnham. 1141 p. 